\title{
Penerapan Konsep Manajemen Berbasis Genetik pada Peningkatan Kinerja Sekolah Inklusi
}

\author{
Venny Oktaviany* dan Indra Halim \\ Pendidikan Guru Sekolah Dasar, STKIP Kusuma Negara, Indonesia \\ *venny_oktaviany@stkipkusumanegara.ac.id
}

\begin{abstract}
Abstrak
Tujuan penelitian ini adalah untuk menerapkan model manajemen berbasis genetik dan mendapatkan gambaran tentang efektifitas dan efisiensi sekolah inklusi. Manajemen berbasis genetik adalah pengelolaan atas segala usaha bersama untuk mendayagunakan seluruh sumber-sumber, baik secara personal maupun material, bertujuan untuk tercapainya efektifitas dan efisiensi guna menunjang tercapainya tujuan pendidikan di sekolah secara optimal melalui fokus pada satu kecerdasan sehingga setiap orang akan merasa nyaman, pas dengan apa yang mereka lakukan dan pas dengan mesin kecerdasannya. Metode analitis data yang digunakan dalam penelitian ini adalah analisis data yang bersifat kualitatif dengan deskriptif analitik non statistik yang bertujuan untuk menganalisis personaliti genetik ditinjau dari tes genetik. Penelitian ini dilakukan di Bizsmart Sekolah Inklusi, dengan subjek penelitian adalah seluruh sumber daya manusia yang terlibat beserta seluruh siswa berkebutuhan khusus. Instrumen penelitian adalah hasil evaluasi siswa dan wawancara. Hasil penelitian menunjukkan bahwa dengan cara memetakan berdasarkan konsep manajemen genetik sangat membantu siswa, guru dan tenaga pendidik lainnya untuk dapat lebih mudah dan nyaman dalam proses pembelajaran dan pengelolaan manajemne, karena menyesuaikan metode dengan potensi genetik masing-masing, sehingga dalam pelaksanaannya dapat meningkatkan kinerja sekolah inklusi.
\end{abstract}

Kata kunci: manajemen, genetik, sekolah inklusi.

\section{PENDAHULUAN}

Upaya pemerintah untuk melaksanakan pendidikan inklusi telah dituangkan melalui Peraturan Pemerintah (PP) Nomor 72 tahun 1991 tentang pendidikan Luar Biasa, Undang-Undang Republik Indonesia Nomor 20 tahun 2003 tentang sistem Pendidikan Nasional tentang pendidikan bagi peserta didik penyandang disabilitas sebagaimana Pasal 5 ayat (2) bahwa warga negara yang memiliki kelainan fisik, mental/intelektual, sosial, dan emosional berhak memperoleh pendidikan khusus. Selain itu Permendiknas nomor 70 tahun 2009 tentang Pendidikan Inklusi bagi peserta didik yang memiliki kelainan dan memiliki potensi kecerdasan dan/atau bakat istimewa, serta Surat Edaran Dirjen Manajemen Pendidikan Dasar dan Menengah Kemendiknas Nomor 380/C/C6/MN/2003, tanggal 20 Januari 2003, yakni: Setiap kabupaten/kota diwajibkan menyelenggarakan dan mengembangkan pendidikan inklusif di sekurang-kurangnya 4 (empat) sekolah yang terdiri dari SD, SMP, SMK.

Dari hal tersebut di atas negara telah menjamin bahwa anak-anak spesial tersebut mendapat hak yang sama dengan anak-anak yang lain dalam hal hak untuk mendapatkan pendidikan. Namun walaupun demikian kita tidak dapat tinggal diam dan menunggu pemerintah melakukan sesuatu bagi mereka. Hal ini tidak hanya terjadi di Indonesia, di seluruh duniapun negara tidak dapat mampu 
menangani hal ini sendiri, sehingga diperlukan banyak bantuan dari gerakan swadaya masyarakat untuk bisa bersama-sama mewujudkan pendidikan yang layak bagi para Anak berkebutuhan Khusus (ABK). Jumlah mereka semakin banyak, mereka menunggu kita semua untuk bangkit dan melakukan sesuatu sehingga perlunya kita melakukan sesuatu untuk anak-anak tersebut. ABK atau sering disebut juga SBK yaitu siswa berkebutuhan khusus didefinisikan sebagai siswa yang memiliki perbedaan fisik, mental atau tampilan perilaku baik lebih tinggi atau lebih rendah berdasarkan norma yang ada, sehingga membutuhkan pelayanan khusus (Damayanti, Hamdan \& Khasanah, 2017).

Berdasarkan informasi atas pendataan Kementrian Pendidikan dan Kebudayaan Direktorat Jendral Pendidikan Dasar dan Menengah Direktorat Pembinaan Pendidikan Khusus bahwa secara umum sampai dengan saat ini belum ada angka yang pasti tentang jumlah $\mathrm{ABK}$ di Indonesia. Namun, yang jelas jumlah mereka yang belum memperoleh hak pendidikan masih sangat banyak jumlahnya. Data resmi Direktorat Pendidikan Sekolah Luar Biasa tahun 2017 menyebutkan bahwa jumlah ABK yang sudah mengikuti pendidikan formal baru mencapai $24,7 \%$ atau 78.689 anak dari populasi anak cacat di Indonesia, yaitu 318.600 anak (Maulipaksi, 2017). Hal ini menjelaskan bahwa masih terdapat sebanyak 65,3\% ABK yang masih terseklusi, termarjinalisasikan dan terabaikan hak pendidikannya. Bahkan angka tersebut diperkirakan dapat jauh lebih besar jumlahnya mengingat kecilnya angka prevelensi yang digunakan, yakni 0,7\% dari populasi penduduk serta masih sangat buruknya sistem pendataan yang ada.

Selain itu juga sebagaimana data yang diperoleh dari Kementrian Pendidikan dan Kebudayaan yang disampaikan dalam Maulipaksi (2017), hingga saat ini terdapat paling sedikit 25 kabupaten/kota yang telah menyatakan komitmennya untuk mentuntaskan masalah pendidikan inklusif. Lebih lanjut, setiap kabupaten tersebut mewajibkan beberapa sekolah yang ditunjuk untuk menerima siswa ABK. Hal ini karena jumlah ABK di Indonesia ternyata cukup besar, diperkirakan kurang lebih ada 4,2 juta ABK, atau jika menggunakan asumsi PBB dinyatakan bahwa paling sedikit 10\% anak usia sekolah (5-14) adalah menyandang kebutuhan khusus. Namun, saat ini jumlah anak berkebutuhan khusus yang telah tertangani dan masuk dalam pendidikan inklusif baru sekitar 116.000 anak dari total 300.000 anak, selebihnya masih di bawah asuhan orang tua masing-masing, sisa sekitar 184.000 ABK di Indonesia belum menikmati indahmya pendidikan layaknya anak dengan kondisi mental dan fisik normal.

Menurut penelitian Yusuf (2012) bahwa berdasarkan perkembangan ilmu pengetahuan dan teknologi dalam bidang pendidikan ABK, ditemukan banyak bukti baru, bahwa ABK dengan berbagai hambatan fisik dan intelektualnya mereka mampu mengikuti pendidikan di sekolah-sekolah reguler dengan guru dan sumberdaya lainnya telah tersedia di sekolah, kemudian kurikulum dan pembelajaran dengan desain khusus sehingga memungkinkan setiap ABK mendapatkan layanan yang sesuai dengan kebutuhan masing-masing. Temuan ini semakin memperjelas bahwa pendekatan sosial di sekolah dapat mengatasi masalah hambatan dalam pendidikan ABK.

Permasalahan tersebut memungkinkan perlunya terobosan bentuk pelayanan pendidikan bagi $\mathrm{ABK}$ berupa penyelenggaraan pendidikan inklusi. Sehingga $\mathrm{ABK}$ dapat segera tertangani dan terlayani. 


\section{Kajian Teori}

Poniman (2013) menyatakan bahwa setiap orang memiliki kecerdasan dominan tunggal yang dibawa semenjak lahir. Pada kontek manajemen pada konsep genetik tentang fokus pada hanya satu mesin kecerdasan dominan saja yang bersandar secara ilmiah kepada pendekatan psikologi analitis yang dipelopori oleh Carl Gustaf Jung (dalam Poniman \& Hidayat, 2015) dikompilasi dengan teori the whole brain concept dari Ned Herrmann dan teori triune brain yang dikembangkan Paul McLean. Paradigma awal yang digunakan adalah psikologi analitis (Rafianti \& Pujiastuti, 2017). Penempatan manusianya sendiri menggunakan pendekatan keperilakuan yang humanis. Manusia dianggap memiliki potensi genetis yang sudah luar biasa. Ketika potensi ini mendapat lingkungan dan tempaan yang tepat serta terencana, maka hasil yang keluar pada akhirnya akan menjadi ekstra luar biasa.

\section{Manajemen}

Luther Gulick (dalam Lunenburg \& Ornstein, 2012) memberikan konsep manajemen sebagai, planning, organizing, staffing, directing, coordinating, reporting, and budgeting (POSDCoRB). Teori Luther Gulick ini lebih lanjut dijelaskan oleh Lunenburg \& Ornstein (2012) sebagai berikut: (a) perencanaan berkaitan dengan garis besar dari pengembangan hal yang harus dicapai dan metodenya, juga prediksi atas tindakan dimasa yang akan datang serta arah organisasi; (b) pengorganisasian, menetapkan struktur organisasi secara formal melalui penyusunan pembagian kerja, penetapan, dan koordinasi untuk pelaksanaan perencanaan; (c) staffing, melibatkan seluruh personil meliputi fungsi seleksi, pelatihan, serta pengembangan staf dan menjaga kondisi kerja yang menguntungkan; (d) pengarahan, berkaitan erat dengan kepemimpinan, termasuk tugas yang berkelanjutan dalam membuat keputusan, dan mengevaluasi bawahan dengan benar; (e) koordinasi, melibatkan seluruh aktivitas dan upaya yang dibutuhkan bersama dalam organisasi untuk mencapai tujuan; (f) pelaporan, melalui pemeriksaan pencatatan, penelitian, dan inspeksi; memastikan bahwa pelaksanaan sudah sesuai dengan rencana; mengambil tindakan korektif bila diperlukan, dan melaporkan kepada penanggung jawab; (g) penganggaran, menyangkut semua kegiatan yang berkaitan dengan penganggaran, termasuk perencanaan fiskal, akuntansi, dan pengendaliannya.

Menurut Everard, Moris, dan Wilson (dalam Lunenburg \& Ornstein, 2012) aktivitas manajemen berkaitan dengan "maintenance and development resources" yang meliputi: (a) Human-selection, job design, performance management, career planning, trainning, project work, coaching; (b) material-purchasing, stock control, asset management; (c) financial-budgeting, cost-raising, cost/benefit analysis.

\section{Manajemen Berbasis Genetik}

Pelaksanaan manajemen pada konsep yang yang berbasis genetik pada dasarnya tetap menggunakan konsep dan sistem sumber daya yang saat ini dikembangkan para ahli dan praktisi manajemen (Monde, 2017), hanya saja pada tataran eksekusinya menggunakan skema STIFIn (Poniman \& Ariezta, 2018) yang dijabarkan sebagai fungsi pengindraan (Sensing, disingkat S), fungsi pikiran 
(Thinking, disingkat $\mathrm{T}$ ), fungsi perasaan (feeling, disingkat $\mathrm{F}$ ), fungsi intuisi (Intuiting, di singkat I), dan yang terakhir fungsi penengah (Insting, disingkat In).

Konsep STIFIn dalam hal ini disebut simple karena bersifat multy-angel theory. Hal ini dimaksudkan bahwa STIFIn dapat digunakan untuk menjelaskan teori kecerdasan dan personality dari berbagai disiplin ilmu lainnya, sebagaimana konsep otak kiri dan otak kanan (Roger W. Sperry) atau pembagian neokortek sebagai otak atas dan limbik sebagai otak bawah (Paul Broca) atau pembagian 6 Hexagonal Holland (John Holland) juga konsep DISC (John Geier dan Thomas International) atau bahkan teori lama Hippocrates dan Galenus dapat dengan mudah dibedah menggunakan STIFIn (Gunadi, 2016; 2018).

\section{Pendidikan Inklusi}

Sue Stubb (2002) mengatakan, bahwa konsep pendidikan inklusif memiliki lebih banyak kesamaan dengan konsep yang melandasi pendidikan untuk semua, dan peningkatan mutu sekolah. Selanjutnya disampaikan pula bahwa pendidikan inklusi merupakan pergeseran dari kecemasan kelompok tertentu yang telah menjadi suatu upaya yang fokus mengatasi hambatan belajar dan berprestasi.

Definisi tentang pendidikan inklusi lahir dari seminar agra pada tahun 1998, yang merumuskan bahwa pendidikan inklusi di dalamnya: (a) lebih luas daripada pendidikan formal: mencakup pendidikan di rumah, masyarakat, sistem nonformal dan formal, (b) mengakui bahwa semua anak dapat belajar, (c) memungkinkan struktur, sistem dan metodelogi pendidikan memenuhi kebutuhan semua anak, (d) mengakui dan menghargai berbagai perbedaan pada diri anak: usia, gender, etnik, bahasa, kecacatan, status HIV/Aids dan lain-lain, (e) merupakan proses yang dinamis yang senantiasa berkembang sesuai dengan budaya dan konteksnya, (f) merupakan bagian dari strategi yang lebih luas untuk mempromosikan masyarakat yang inklusif.

Definisi terbaru lainnya dari Ofsted ( dalam Ainscow, 2001), menyampaikan bahwa sekolah yang mempraktekkan pendidikan inklusif merupakan sekolah yang memperhatikan pengajaran dan pembelajaran, pencapaian, sikap serta kesejahteraan setiap siswanya. Selanjutnya disampaikan pula bahwa skolah yang efektif adalah sekolah yang mempraktekkan pendidikan inklusif.

Definisi di atas menggambarkan sebuah model pendidikan inklusif yang berdasarkan pada berbagai konsep utama tentang suatu sistem, stakeholder, proses, dan sumber dayanya. Konsep utama yang terkait dengan pendidikan inklusif tersebut adalah: (a) konsep-konsep tentang anak, yaitu: semua anak berhak memperoleh pendidikan di dalam sekolah, semua anak dapat belajar, dan siapa pun dapat mengalami kesulitan dalam belajar, semua anak membutuhkan dukungan untuk belajar, pengajaran yang terfokus kepada anak bermanfaat bagi semua anak; (b) konsep-konsep tentang sistem pendidikan dan persekolahan, yaitu: pendidikan lebih luas dari persekolahan formal, sistem pendidikan yang fleksibel dan responsive, lingkungan pendidikan yang memupuk kemampuan dan ramah, peningkatan mutu sekolah-sekolah yang efektif, pendekatan sekolah yang menyeluruh dan kolaborasi antar mitra; (c) konsep-konsep tentang keberagaman dan diskriminasi, yaitu: memberantas diskriminasi dan tekanan untuk mempraktekkan eksklusi, merespon/merangkul keberagaman sebagai sumber kekuatan, bukan masalah, pendidikan inklusif mempersiapkan siswa untuk masyarakat yang menghargai dan menghormati perbedaan; (d) konsep-konsep 
tentang proses untuk mempromosikan inklusi, yaitu: mengidentifikasi dan mengatasi hambatan inklusi, meningkatkan partisipasi nyata bagi semua orang, kolaborasi, kemitraan, metodologi partisipatori, penelitian tindakan, penelitian kolaboratif; (e) konsep-konsep tentang sumberdaya, yaitu: membuka jalan ke sumberdaya setempat, redistribusi sumberdaya yang ada, memandang orang (anak, orang tua, anggota kelompok termajinalisasi dan lain-lain) sebagai sumberdaya utama, sumber daya yang tepat yang terdapat di dalam sekolah dan pada tingkat lokal dibutuhkan untuk berbagai anak, misalnya braille, alat asistif.

Di Indonesia secara resmi yang dimaksudkan dengan pendidikan inklusif oleh pemerintah dan dirujuk oleh masyarakat adalah pendidikan inklusi sebagai sistem layanan pendidikan yang mengikutsertakan ABK untuk belajar bersama dengan anak sebayanya di sekolah reguler yang terdekat dengan tempat tinggal mereka. Penyelenggaraan pendidikan inklusif menuntut pihak sekolah melakukan penyesuaian baik dari segi kurikulum, sarana prasarana pendidikan, maupun pendidikan, serta sistem pembelajaran yang disesuaikan dengan kebutuhan individu para peserta didik (Herawati, 2012).

\section{METODE PENELITIAN}

Metode yang digunakan dalam penelitian ini adalah analisis data yang bersifat kualitatif dengan deskriptif analitik nonstatistik. Analisis ini digunakan untuk mendapatkan hasil penelitian yang berkaitan dengan penerapan konsep manajemen berbasis genetik. Proses analisis data dilakukan bersamaan dengan pengumpulan data melalui beberapa tahapan yang dimulai dari proses pengumpulan data, reduksi data, penyajian data dan verifikasi atau penarikan kesimpulan (Huberman \& Miles, 1992). Penelitian ini mengambil lokasi di Bizsmart School, sekolah inklusi berbasis potensi genetik dengan pertimbangan bahwa sekolah ini benar-benar telah menerapkan sistem manajemen yang berbasis genetik. Target penelitian adalah seluruh sumber daya manusia yang ada beserta seluruh siswa berkebutuhan khusus yang ada di sekolah tersebut.

\section{HASIL DAN PEMBAHASAN}

Hasil penelitian menjelaskan bahwa implementasi penerapan konsep manajemen berbasis genetik pada sekolah inklusi ini menggunakan metode yang merupakan teknik yang digunakan untuk mencapai tujuan prinsip dan praktik-praktik yang baik dalam pembelajaran dan pengajaran dimana manusia diciptakan unik dengan kekurangan dan potensi dirinya. Makin baik sebuah metode, makin efektif pula fungsinya sebagai alat pencapaian tujuan. Menurut Djamarah \& Zain (2000), keanekaragaman metode pembelajaran disebabkan oleh adanya pengaruh dari berbagai faktor, di antaranya: (a) Tujuan dengan berbagai jenis dan fungsinya; (b) Peserta didik dengan berbagai tingkat kematangannya; (c) Situasi dalam pembelajaran dengan berbagai keadaannya; (d) Fasilitas yang mendukung pembelajaran dengan berbagai kualitas dan kuantitasnya; (e) Pribadi guru serta kemampuan profesionalitas yang berbeda-beda.

Sebagaimana anak normal lainnya, ABK adalah anak yang memerlukan perhatian, kasih sayang yang lebih spesifik, baik itu di lingkungan rumah dan sekolah. Spesifikasi tersebut ada disebabkan karena mereka memiliki berbagai 
hambatan dalam pertumbuhannya dan memiliki karakteristik khusus yang berbeda dengan anak pada umumnya.

Berdasarkan hasil penelitian yang dilakukan dapat dikemukakan bahwa implementasi metode manajemen berbasis genetik ini di awali dengan tes potensi genetik melalui tes Fingerprint atau DNA, yaitu sebuah tes yang dilakukan dengan cara men-scan kesepuluh ujung jari untuk mendapatkan sidik jari dengan alat fingerprint. Sidik jari ini membawa informasi tentang komposisi susunan syaraf yang kemudian dianalisis dan dikaitkan dengan belahan otak tertentu yang dominan berperan sebagai sistem operasi serta sekaligus menjadi mesin kecerdasan seseorang yang diberi nama STIFIn yang merupakan singkatan dari sensing (disingkat $\mathrm{S}$ ), thinking (disingkat $\mathrm{T}$ ), intuiting (disingkat I), feeling (disingkat F), insting (disingkat In). Dengan menggunakan metode kajian literatur kemudian dianalisis sebagai keberadaan mesin kecerdasan dan kepribadian genetik yang mendorong pengembangan potensi kecerdasan manusia yang lebih efektif, dimana dapat diketahui bahwa tiap individu dipicu dari sistem operasi 5 belahan otak manusia, yakni, (1) limbik kiri, merupakan tipe sensing yang menghasilkan karakter terkait kerja fisik, suka sesuatu yang riil, dan bagus dalam menghafal, (2) neokortek kiri, merupakan tipe thinking yang menghasilkan karakter yang terkait dengan berfikir logis, (3) neokortek kanan, intuiting yang menghasilkan karakter kreatif, (4) limbik kanan, merupakan tipe feeling yang menghasilkan karakter yang perasa dan jiwa sosial yang bagus, dan (5) batang otak, merupakan tipe insting yang menghasilkan tipe yang serba bisa dan suka bekerja dengan spontan.

Selanjutnya dari diketahuinya kelima karakter diatas maka diturunkan menjadi pola asuh dalam pemetaan sistem pembelajaran dan pengajaran pada siswa $\mathrm{ABK}$, yakni (1) sensing, tipe siswa yang diasuh dengan kalimat menekan dan bersyarat, untuk mencapai prestasinya siswa ini ditekankan atau ditargetkan, dan diberi hadiah setelah berhasil, (2) thinking, siswa ini akan bersemangat dalam belajar ketika nasihat yang diberikan kepadanya menggunakan kalimat logis dan masuk akal, (3) intuiting, yang nyaman apabila nasehat yang diberikan kepadanya dengan menggunakan kalimat inspiratif yaitu yang mengandung hikmah dan nuasa masa depan, (4) feeling, akan terkondisi dengan baik apabila lemah lembut, sambal dielus pundaknya, terakhir (5) insting, tipe siswa ini suka dinasihati dengan kalimat pendek, spontan, dan disalurkan dalam berbagai kegiatan.

Selain itu tes sidik jari ini juga mampu membedakan bakat mesin kecerdasan dan personality seseorang yang secara genetik nyata. Bahkan susunan syaraf tersebut dapat diprediksi letak dominasi mesin kecerdasanya yang dikemudikan dengan dua cara yang berbeda yaitu: kemudi introvert (i) atau ekstrovert (e). Mesin kecerdasan dengan kemudi i atau e tersebutlah yang kemudian disebut dengan personality. Tes mesin atau karakter kecerdasan STIFIn Personality merupakan tes mengenali mesin keceradasan yang dominan dimiliki oleh peserta didik maupun para guru dan tenaga pendidik lainnya.

Sehingga pada dasarnya setiap peserta didik, pendidik dan tenaga pendidik memiliki karakter kecerdasan yang dominan. Karakter yang dominan tersebutlah yang menjadi kekuatan utama untuk meningkatkan prestasi belajar yang selanjutnya menjadi penting dan kunci bagi setiap individu yang ada di Sekolah Inklusi Bizsmart untuk mengetahui potensi/kekuatan yang ada pada dirinya dalam mengoptimalkan kemampuan. 
Dalam menerapkan pola genetik ini, maka guru dan tenaga pendidik diberi pelatihan tentang konsep dan pola asuh berbasis genetik untuk lebih fokus dalam meningkatkan kualitas kegiatan belajar mengajar. Targetnya bahwa setiap siswa ABK tersebut dapat mandiri ke arah kondisi normalnya dan dapat terus meningkatkan prestasinya. Para guru harus mengevaluasi kondisi anak didik sebelum dan sesudah dilakukan pola sistem genetik ini.

Dalam penelitian ini pelaksanaan program berbasis genetik dianggap sebagai kiat yang efektif dalam arti metode ini cukup mudah dipelajari dan dipraktekkan dan dalam waktu singkat dapat mengendalikan siswa ABK dengan baik, sehingga sangat efisien dalam sekali investasi untuk selanjutnya, serta hasilnya secara kualitatif siswa, guru dan tenaga pendidik lainnya menjadi nyaman dan kualitas belajar mengajar meningkat.

Pada prakteknya pada dunia pendidikan, menurut Nistiningtyas (2013) terdapat beberapa alasan mengapa memilih metode STIFIn yaitu guru bisa dengan mudah mengenali cara belajar masing-masing peserta didiknya yang berbedabeda. Selain itu menurut Gunadi (2016; 2018) dalam kajian tentang pengembangan model kepemimpinan sekolah dengan pendekatan metode STIFIn, terbukti bahwa di sekolah Inklusi Bizsmart dapat menjelaskan bahwa: (1) Mesin kecerdasan yang dimiliki oleh pemimpin atau kepala sekolah, guru atau tenaga kependidikan akan menentukan gaya dalam memimpin (bentuk interaksi komunikasi) yang dilakukan, (2) Dengan mesin kecerdasan dan personaliti genetik (PG) yang dimiliki kepala sekolah akan dengan mudah mengendalikan bawahannya sesuai dengan mesin kecerdasan dan personaliti genetik, (3) Proses interkasi - komunikasi efektif dilakukan dengan saling memahami masing-masing PG. Kepala sekolah akan melakukan proses interaksi - komunikasi kepada bawahan (guru dan tenaga kependidikan) sesuai dengan PG-nya. Demikian pula sebaliknya, bawahan dapat memperlakukan kepala sekolah dengan baik.

Selain itu melalui pemanfaatan metoda STIFIn pada bidang managerial di sekolah Inklusi Bizsmart yaitu melalui pola kepemimpinan dengan menggunakan metoda STIFIn dipercaya dapat membangun pola hubungan antara pimpinan dengan bawahan yang lebih efektif dan kondusif karena masing-masing pihak telah memahami karakter berdasarkan mesin kecerdasan dan personality genetik masing-masing. Sehingga iklim yang terbangun semakin kondusif untuk mencapai tujuan sekolah. Selain itu juga melalui mesin kecerdasan dan drive kecerdasan akan dapat menentukan jenis personality genetic (PG) kepala sekolah, guru dan tenaga kependidikan. PG inilah yang disebut dengan kecerdasan atau karakter dan melalui PG ini pula masing-masing kepala sekolah, guru dan tenaga kependidikan berinteraksi-berkomunikasi dengan saling memahami masingmasing PG. Dari proses interaksi-komunikasi antar PG tersebut maka masingmasing individu akan menentukan prestasi dan kinerja baik kepala sekolah, guru dan tenaga kependidikan, maupun sekolah. Dengan demikian, peserta didik lebih merasa nyaman dan enjoy dalam proses pembelajaran karena guru dapat memahami gaya belajar siswa melalui hasil tes tersebut, kemudian peserta didik lebih terkonsentrasi sehingga guru pun dapat lebih memaklumi dan lebih menaruh perhatian yang maksimal terhadap kemajemukan mesin kecerdasan tiap-tiap peserta didiknya. Hal ini akan berdampak pada peningkatan prestasi belajar peserta didik, serta hal ini sesuai dengan pendapat Rafianti \& Pujiastuti (2017) yang menyatakan dalam hasil penelitiannya bahwa saat ini sudah dikenal berbagai 
metode untuk memenuhi tuntutan perbedaan individu, salah satunya adalah STIFIn yaitu metode untuk menentukan dominasi kecerdasan mesin untuk membuat siswa lebih nyaman dalam proses pembelajaran.

Hal senada menurut Alindra (2018) pada hasil penelitian mereka tentang aplikasi pengembangan karakter siswa, bahwa yang dilakukan oleh guru terlebih dahulu memahami karakter pada setiap peserta didik kemudian mengenali bakatnya dan selanjutnya menyalurkan bakatnya ke dalam kegiatan pengembangan diri. Hal ini dilakukan dengan menggunakan tes STIFIn, untuk mengenali minat, bakat, berpikir kreatif, logis, kerja otak kiri dan otak kanan seseorang, keseluruhannya ditinjau dari psikometri seseorang yang prinsipnya diketahui dengan membaca sepuluh jari seseorang.

Sejauh ini memang masih banyak eksplanasi ilmiah yang masih diperlukan dari metoda STIFIn. Peluang penelitian lebih lanjut amat terbuka untuk hal ini. Kajian ilmiah tentang kaitan pola genetika dengan kecenderungan mesin kecerdasan masih sangat perlu dikembangkan, sehingga keterlibatan neurosains yang lebih mendalam tentu akan lebih diperlukan, sehingga kajian tentang metode STIFIn yang sedang digunakan secara massif ini dapat lebih diterima secara ilmiah.

\section{KESIMPULAN}

Bahwa ABK adalah anak yang mengalami keterbatasan atau keluarbiasaan, baik fisik, mental-intelektual, sosial, maupun emosional, yang berpengaruh secara signifikan dalam proses pertumbuhan dan perkembangannya dibandingkan dengan anak-anak lain yang seusia dengannya sehingga memiliki permasalahan yang berbeda-beda dan memerlukan penanganan yang khusus. Jika ABK ini mendapatkan perhatian tersendiri dan penanganan yang tepat maka akan dapat ditemukan keterampilan yang sesuai dengan minat dan bakat yang mereka miliki, dan anak akan dapat hidup lebih mandiri dan bahagia. Namun sebaliknya, jika anak berkebutuhan khusus tidak ditangani dengan tepat akan berdampak dengan semakin bergantungnya anak kepada orang didekatnya dan bakatnya akan semakin tenggelam dan tidak terlhat.

Dalam penanganannya dibutuhkan orang-orang sekitar seperti orang tua ataupun keluarga yang mampu memberikan pelayanan kepada $\mathrm{ABK}$ dan tanggung jawab mereka untuk memberikan hak yang sama kepada ABK dan non ABK. Sehingga disinilah pentingnya menempatkan anak pada sekolah yang sesuai dengan kebutuhan anak untuk mempermudah pemberian materi pembelajaran pada anak tanpa membedakan siswa ABK dengan siswa normal. Memberikan anak kesempatan untuk mengembangkan minatnya yang akan berujung pada penemuan potensi alami pada $\mathrm{ABK}$ dan membiarkan anak bersosialisasi dengan lingkungan sekitarnya.

Dari hasil penelitian tersebut diatas dapat disimpulkan bahwa untuk peningkatan kinerja sekolah inklusi tidak harus menggunakan cara formal, namun juga dapat dicoba dengan menggunakan cara non formal dengan peneran konsep manajemen berbasis genetik. 


\section{UCAPAN TERIMA KASIH}

Dengan terselesaikannya penelitian ini, penulis mengucapkan banyak terimakasih kepada Direktorat Riset dan Pengabdian Masyarakat Direktorat Jendral Riset dan Pengembangan Kementrian Riset, Teknologi, dan Pendidikan Tinggi yang telah memberikan dukungan dalam bentuk Hibah Penelitian Dosen Pemula (PDP), sehingga penelitian ini dapat terlaksana dengan baik, lancar dan sukses.

\section{REFERENSI}

Ainscow, M. (2001). Developing inclusive schools: implications for leadership. Extraído el, 25, 1-6.

Alindra, A. L. (2018). Kajian Aksiologi Metode STIFIn dalam Pemetaan Mesin Kecerdasan Manusia. Jurnal Filsafat Indonesia, 1(1), 23-29.

Damayanti, T., Hamdan, S.R., \& Khasanah A.N. (2017). Kompetensi Guru dalam Proses Pembelajaran Inklusi pada Guru SD Negeri Kota Bandung. SCHEMA: Journal of Psychological Research, 3(1), 79-88.

Djamarah, S. B., \& Zain, A. (2000). Metode Pembelajaran. Jakarta: Rineka Cipta.

Gunadi, I. (2016). Education and Development of Student's Character Based on Personality Genetic. Proceeding International Conference on Education and Training, 410-416.

Gunadi, I. (2018). Pengembangan Model Kepemimpinan Sekolah dengan Pendekatan Konsep STIFIn [PDF file]. Retrieved from http://stifinbekasi.com/wp-content/uploads/2019/03/Pengembangan-ModelKepemimpinan-Sekolah-dengan-Pendekatan-Konsep-STIFIn.pdf

Herawati, N. I. (2012). Pendidikan Inklusif. Eduhumaniora: Jurnal Pendidikan Dasar, 2(1), 1-11.

Huberman, A. M., \& Miles, M. B. (1992). Analisis Data Kualitatif. Jakarta: Penerbit Universitas Indonesia.

Lunenburg, F. C., \& Ornstein, A. C. (2012). Educational Administration. New York: Wadsworth.

Maulipaksi, D. (2017). Sekolah Inklusi dan Pembangunan SLB Dukung Pendidikan Inklusi [HTML file]. Retrieved from https://www.kemdikbud.go.id/main/blog/ 2017/02/sekolah-inklusi-danpembangunan-slb-dukung-pendidikan-inklusi.

Monde, A. (2017). Era Genetik: Era Mengembangkan SDM, Jakarta: Qurrotu A'yun.

Nistiningtyas, N. (2013). Tes STIFIn Dalam Mencapai Prestasi Belajar Siswa pada Mata Pelajaran Tarikh di Kelas VIII dI SMP IT Al-Amri Probolinggo (Disertasi Doktor tidak dipublikasi). UIN Sunan Ampel, Surabaya.

Peraturan Menteri Pendidikan Nasional Republik Indonesia. (2009). Pendidikan Inklusif bagi Peserta Didik yang Memiliki Kelainan dan Memiliki Potensi Kecerdasan dan/atau Bakat Istimewa. Jakarta: Kemenkumham.

Peraturan Pemerintah Republik Indonesia. (1991). Pendidikan Luar Biasa. Jakarta: Kemenkumham.

Poniman, F. (2013). Penjelasan Hasil Tes Stifin, Mengenali Cetak Biru Hidup Anda. Jakarta: PT. Stifin Fingerprint.

Poniman, F., \& Ariezta, M. (2018). Panca Rona, Jakarta: Yayasan STIFIn. 
Poniman, F., \& Hidayat, Y. (2015). Manajemen HR STIFIn Terobosan Untuk Mendongkrak Produktivitas. Jakarta: PT Gramedia Pustaka Utama.

Rafianti, I., \& Pujiastuti, H. (2017). Analysis of Students'mathematical Power in Terms of Stifin Test. Infinity Journal, 6(1), 29-36.

Undang-Undang Republik Indonesia. (2003). Sistem Pendidikan Nasional. Jakarta: Kemenkumham.

Yusuf, M. (2012). Kinerja Kepala Sekolah dan Guru dalam Mengimplementasikan Pendidikan Inklusif. Jurnal Pendidikan dan Kebudayaan, 18(4), 382-393. 